\title{
Mediating Effect of Idealized Influence Between Relationship Emotional Intelligence and Intention to Perform: Conceptual Study
}

\author{
Gopalan Raman ${ }^{1}, \mathrm{Ng}$ Lee Peng ${ }^{1}, \&$ I-Chi Chen ${ }^{3}$ \\ ${ }^{1}$ Department of Business and Administration, Universiti Tunku Abdul Rahman, Perak, Malaysia \\ ${ }^{2}$ Department of Marketing, Universiti Tunku Abdul Rahman, Perak, Malaysia \\ Correspondence: Gopalan Raman. E-mail: gopalanr@utar.edu.my
}

Received: June 11, $2020 \quad$ Accepted: August 25, $2020 \quad$ Online Published: September 24, 2020

doi:10.5539/ass.v16n10p69

URL: https://doi.org/10.5539/ass.v16n10p69

\begin{abstract}
Academics have an enormous endeavor to advance in higher education institutions, and responsiveness regarding to their performance, leaders' emotional intelligence and leaders' idealized influence are fundamental. Research on emotional intelligence and job performance is expanding at considerable pace, but emotional intelligence and intention to perform has received less attention. In addition, study on transformational leadership towards intention to perform has been established but study on a single component, idealized influence has been eluded. To address this gap in the literature, this study is intended to examine the leader's emotional intelligence abilities and idealized influence towards academic's intention to perform. Drawing from attribution theory and transformational leadership, the study hypothesized that emotional intelligence and intention to perform will be mediated by idealized influence.
\end{abstract}

Keywords: emotional intelligence, idealized influence, intention to perform

\section{Introduction}

Intention to perform set the hook in this research leading to a stronger and well-conceived set of understanding of the intention itself. Interestingly, intention is an expression of an individual towards a behavior either as a voluntary intention or involuntary intention (Klass, 2009). Furthermore, intention is a "personal decision about whether or not to pursue a specific job to an extent of dedication to an endeavor, and persistence" (Pritchard, 1976). Therefore, there seems to be an obvious reason why an individual developed this feelings or expression of intention but perhaps the influence may arise from an individual or between individuals. Intention is described as a behavioral intention that captures an individual's motivation to perform a behavior and serves as an indicator of the efforts of individuals who plan on doing the behavior (Ajzen, 1991; Ajzen \& Fishbein, 1975). Furthermore, intention is the prime determinant of subsequent behavior changes and it has the elements of interventions that strengthen the intention itself (Carver, 1998; Sheeran, 2002; Webb \& Sheeran, 2006). It is also being pointed out that intention as "self-instructions to perform particular behaviors or to obtain certain outcomes" and is usually measured by endorsement of items such as "I intend to do X" (Triandis, 1980). Gomes, Gonçalvesb, Madduxc and Carneiroa (2017) described that intentions are determined by a person's attitude towards a "behavior, subjective norms, and perceived behavioural control". Gomes et al. (2017) further added that the likelihood of performing certain behaviour increases if a person has a positive attitude towards the behaviour (attitudes), feels social pressure to perform the behaviour (subjective norms), and believes that he or she will be successful in performing the behaviour (perceived behavioural control). Unfortunately, the fifth intent which is the, intent to perform is the least explored intention among the five work intentions (Raman, Lee Peng, \& I-Chi, (2020). Zigarmi and Roberts (2012) further added that employees intend to perform as predetermine self-instructional motivational factors towards accomplishment such as performance. As such, this research concluded that intention is a valid proxy of actual performance behaviour. Similarly, Frings, Melichar, and Albery (2016) added that intention can be assumed as discernment that precedes the conduct of the action such as performance-related actions. Finally, intention to perform is the least explored intention in the literature of organization and leadership and is not able to explain the cognitive perspective and strength of intention itself (Raman et al., 2020; Zigarmi \& Roberts, 2012).

Recognizing that performance is dynamic, as it were, it varies inside a person after some time and would encourage impressive advances in our comprehension of job performance and its forerunners (Hofmann \& 
Jacobs, 2012; Sonnentag \& Frese, 2012). Albeit, analysts and experts realize that a employee's performance changes after some time in them, this inside individual performance fluctuation isn't surely known and seen as non-significant (Dalal, Bhave, \& Fiset, 2014). Concluding that variances exits in individual job performance and further understanding the antecedents towards performance is vital (Hofmann, Jacobs, \& Gerras, 1992; Sonnentag \& Frese, 2012; Dalal et al., 2014). Therefore, understanding and acknowledging job performance is not solution to the survival of an organization but what varies and contributes to the job performance itself is a 'survival' and worth researching. In doing so, studies of why an individual "wanted" or "not wanted" to perform is vital as it is a predetermine of one's behavior. The reasoning for this dichotomy is that intentions are the predictor and influenced by factors within the control of the individual in which individual's own belief, attitudes and traits can determine the individual intention. Intentions of individuals are also influenced by the surrounding factors especially the relationship between his or her leader.

Shielding one's desired behaviors and the outcome studied on turnover strongly suggested that intentions are strong predictors of an action such as turnover and the intentions were "to leave" (Lee \& Liu, 2007; Li, Kim, \& Zhao, 2017; Lannoo \& Verhofstadt, 2016). In addition, various studies have been conducted related to intention such as supervisor relationship and work engagement towards intent to quit by Rodwell. William and Gulyas (2017) and the study of management support towards employee's intention to turnover by (Hallikainen, Paesbrugghe, Laukkanen, Rangarajan and Gabrielsson 2017). Intention to quit among academic staff in public universities (Khairunneezam, 2011). In addition, another study is based on the usage of technology and culture towards intention to use (Ouyang, Tang, \& Rong, 2017). Further studies were conducted such as conflict relationship and job burnout, Shaukat, Yousaf and Sanders (2017); empowerment, Kim and Fernandez (2017); transformational leadership, Ariyabuddhiphongs and Kahn (2017); job and job support, Knapp and Smith (2017) and all these are towards turnover intention. It concludes that needing a better understanding on the strength of intention and a construct to be studied as dependent variable can serve meaningful findings to eliminate $\mathrm{X}$ to happen (Roberts \& Zigarmi, 2014; Panchal, Fishman, Camp-Rogers, Starodub, \& Merchant, 2015). Though Panchal et al. (2015) stresses the importance of intentions to be studied, in a similar vein, however it is known that intent to perform is least research of five work intentions (Nimon, Zigarmi, Houson, Witt, \& Diehl, 2011; Roberts \& Zigarmi, 2014). In conclusion, intention to perform is least studied though the significant of it has been ignored towards a behavior (Raman et al., 2020).

\section{Literature Review}

\subsection{Emotional Intelligence}

This characterizes emotional intelligence as a set of four related abilities: perceiving, using, understanding, and managing emotions. Nevertheless, emotional intelligence has been dubious among researchers, nonetheless, generally in light of the fact that logical outcomes have been conflicting, particularly as for the significant association between emotional intelligence and job performance it uncovers a baffling contradictory outcomes, (Vidyarthi, Anand, \& Liden, 2013; Dulewicz \& Higgs, 2000). In this way, it spikes further scrutiny onto job performance and its antecedents, permitting in researching the intention to perform as an essential impetus. While a few investigations have reinforced a positive link between emotional intelligence and employee's job performance, numerous different studies have not. Law, Wong, Huang, and Li, (2008), Law, Wong, and Song, (2004), Lam and Kirby, (2002) found that emotional intelligence is positively related with supervisor's performance. Be that as it may, a few different investigations show non relationship between emotional intelligence and supervisors' performance (Austin, 2004; Day \& Carroll, 2004). Given these conflicting outcomes, cascading model was suggested that successively interfaces the components of emotional intelligence with workers' job performance (Joseph \& Newman, 2010).

\subsection{Idealized Influence}

In the mainstream literature, transformational leadership might be the most noticeable factor in clarifying how leaders can coordinate adherents' alluring conduct and accomplish ideal degree of performance (Antonakis, Avolio, \& Sivasubramaniam, 2003; Moynihan, Pandey, \& Wright, 2012). Expanding on's (Burns 1978) order of two types of leaders, Bass (1985) further distinguished and expounded this new kind of leadership. He contended that the old worldview of leadership request essentially centred on task performance, employee consistence and binding relationship among leaders and followers. Bass (1985) proposed that a change in outlook was expected to see how leaders rouse followers/subordinates by raising their consciousness of hierarchical objectives and hoisting their virtues. He alluded this kind of leadership as transformational leadership (Bass, 1985). Researchers found that the degree of leader's support and the level of influence are among the most significant leadership conditions (Ingersoll, 2001). Influence is characterized as "an intuitive procedure where individuals endeavour to 
persuade others to accept as well as act in specific manners" (Rost, 1993) and especially allude to the way wherein a request is presented. "Leaders have an inclination to utilize influence strategies that structure a leadership style" (Yukl, 2002) in which (Dionne, Yammarino, Atwater, \& Spangler, 2004) depicted idealized influence as leadership with the enunciation of vision, moving objectives and spurring subordinates to work past their personal responsibility so as to accomplish shared objectives. What's more, conduct that connected with idealized influence has motivating pride for others for being associated with the leaders, urging subordinates to go past their personal responsibility to help the group or an organization. In this problem, leaders perform as good examples who are profoundly regarded, trusted, and appreciated by their subordinates.

According to researchers, "leaders with great idealized influence are willing to take risks that are consistent by demonstrating high standards of ethical and moral conduct" (Bass \& Riggio, 2006). In addition, according to Bass and Riggio (2006), idealized influence refers to trust, respect, and esteem on the part of subordinates that arises when leaders are keen to share risks and model behavior that is reliable with their primary values. It likewise alludes to a pioneer's excitement and confidence in making a convincing vision and animating comparative sentiments from subordinates. Scholarly incitement happens when a leader esteems the intellectual skills of their subordinates and empowers development and innovativeness. The inquisitive of norms and idea, the forthcoming of old situations in new ways and personalized reflection occurs when a leader pays consideration to each specific need for accomplishment and progress by acting as a mentor. Moreover, idealized influence signifies the "ability of building confidence in the leader and appreciating the leader by his subordinates, which forms the basis for accepting radical change in the organization" (Simić, 1998). If the leader lacks confidence in his motives and objectives, an attempt to redirect the organization may cause great resistance. You can "lead" people if you make them ready to follow you. In other words, this leader possesses idealized influence towards the employees. An important characteristic in idealized influence is that the leaders do not use their position and abilities to achieve personal interests; however, leaders will direct their employees to use their potential to achieve the goals of the organizations. This is supported by the prior study of (Purvanova \& Bono, 2009) that showed if more with idealized influence behaviours that are displayed by leaders, employees' satisfaction will be higher. In a nutshell, characteristics of leaders with idealized influence will emphasize on trust, displays their important values, highlights the importance of purpose, commitment, and ethical consequences of decision.

An excellent leader will display an idealized leadership and not to be idolized. In addition, it distinguished the significance difference between idealized and idolized that idealized leaders build people up to be leaders; the latter are those who expect unquestioning followers (Avolio \& Locke, 2002). Idealized leader influence would consider every aspect of difficulties, uncompromised norms between colleagues stood together in achieving desired goals set by the organization; above all idealized leaders portray the virtue in them. In doing so, information sharing, and knowledge sharing will be the essence that plays a vital catalyst in idealized influence. But it is summarized that idealized influence refers to leaders' "behaviours that inspire others to change their beliefs and values" (Charbonneau, 2004). The fact that can be argued is idealized influence and leadership transformation model is not as comprehensive or well understood. Yukl (1999) states that leadership model omits some important known behaviours associated with effective leadership, such as influence behaviour.

\subsection{Emotional Intelligence and Intention to Perform}

To serve the purpose of this research, the researchers explored further by seeking research on emotional intelligence towards intention to perform. Emotional intelligence is defined as the "intellectual processes in recognizing, using, understanding, and managing of individual's own and others' emotional status and capability to use those feelings to motivate, plan, and attain the individual and organizational performance (Salovey \& Mayer, 1990). In addition to leaders' technical abilities, knowledge and skills that is supreme to their subordinates, emotional intelligence abilities serve as a catalyst in performance (Vierimaa, 2013). Therefore, emotional intelligence is an ability of an individual in recognizing one's emotion and others by raising the question whether abilities of an individual particularly a leader's ability can influence the "intention" of subordinates towards intention to perform. Particularly relevant to the inclusion of emotional intelligence's characteristic that arises the feeling to motivate, plan and attain the individual performance by defining the intention. Leaders motivate through their emotion's ability and thus leader's emotion ability is a motivation leading to a predetermined behavior of intention to perform. Its further support that, "emotions or feelings may be considered to be the ultimate motivator as they fuel a passion for work and are cognitively rewarding" (Abraham, 2004). An emotionally intelligent leader can monitor his or her own behaviour and understand those of their followers. By understanding their subordinates, such leaders can motivate them to work towards organisational goals, thereby enhancing organisational effectiveness. As an evident from the data gathered 
through literature review, emotional intelligence stands as one of the strongest predictors of transformational leadership (Malhotra \& Kansal, 2017). What distinguishes an emotionally intelligent leader is the combination of head and heart, the ability to understand and effectively apply emotions as a means of connection and influence for his followers Malhotral \& Kansal (2017).

Unfortunately findings shows that research are more related to: emotions towards intention to use by Moons and Pelsmacker, (2012); intention in binge drinking by Carrera, Caballero and Munoz (2012) in marketing domain. As such, further findings were conducted on emotional intelligence and intention. Findings shows that emotional towards intention to complain, Strizhakova and Tsarenko (2017); emotional intelligence and emotional labour, Kim and Park (2016); emotional intelligence and communication competence, Kang and Kim, (2016); workplace bully and emotional intelligence, Kim and Park (2016); studies are towards turnover intention. In conclusion, research in emotional intelligence and job performance has found a significant relationship between them Vratsikh et al. (2016); Deshwal (2016); Sony and Mekoth (2015); Yoke and Panatik (2015) Various studies were conducted on antecedents of intention such as management support and behavioral intention toward using digital (Hallikainen, Paesbrugghe, Laukkanen, Rangarajan, \& Gabrielsson, 2017), work-life balance and intention to leave (Khairunneezam, 2011), conflict relationship and job burnout towards turnover intention (Shaukat, Yousaf, \& Sanders, 2017), empowerment and turnover intention (Kim \& Fernandez, 2017),transformational leadership and turnover intention (Ariyabuddhiphongs \& Kahn, 2017), job or job support towards turnover intention of non-profit employees (Knapp, Smith, \& Sprinkle, 2017), Lee and Chelladurai (2018) on emotional intelligence and turnover intention, as moderator in intention to leave (Pradhan \& Jena, 2018), emotional intelligence and entrepreneurial intention (Miao, Humphrey, Qian, \& Pollack, 2018) and emotional intelligence and career intentions (Walters, 2018). But emotional intelligence and performance has been studied in various relationship or association but studies on emotional intelligence and intention to perform was never explored, leaving a gap in it (Raman et al., 2020).

\subsection{Emotional Intelligence and Leadership}

"Leadership has been a central concept in organization theory" (Teepapal, 2013) and it is an important component in order for the organization to achieve their goals, mission and objectives established (Ridza, Mohd, Muda, \& Wan, 2014). Leadership is about making decisions in which the decision is a binary action that divides choices into two parts, desired and undesired, according to a higher principle or value (Rawls, 1999; Kouzes \& Posner, 2003)). It also defines that "leadership is the process of influencing others to understand and decide what needs to be done and how to do it, as well as the process of facilitating individual and collective efforts to accomplish shared objectives" (Yukl, 2002). Emotional intelligence is slowly growing to become the decisive component for leaders to inspire employees and encourage in building tight relationships between them. The evolvement, dynamic and globalization of business environment have led the organizations to be more emphasized on leadership. In this study, we focus on the investigation of how four-branch model by (Salovey \& Mayer, 1990) which characterizes emotional intelligence as a set of four related abilities of a leader: perceiving, using, understanding, and managing emotions have impact on employee's performance.

Leadership is concentrated on people-centric, where leaders should understand that different viewpoints are important for leadership that is emotionally intelligent. Leaders must clearly understand about others feeling and be inspired to share their feelings especially to their employees as they are the one who facilitate leaders to accomplish the tasks towards objectives. Apart from this, "emotional intelligence is becoming significantly important towards effective leadership as leaders able to comprehend the emotions and emotionality within" mentioned by (James, Turnbull \& Arroba, 2005). Therefore, the leaders that are unable to control over their emotions will cause their emotions to govern over them. Nevertheless, there are many different results and findings exhibited by prior researchers regarding the impact of emotional intelligence on leadership. There are some recent findings proved that leadership is directly associated with emotional intelligence, which is supported by (Alston, 2009; Hatfield, 2009). In addition, researchers did specify that emotional intelligence incorporates social interactions inherent in leadership responsibilities (Nelson \& Low, 2011; Salovey \& Mayer, 1990) showed evidences that indicates emotional intelligence has potential to improve on individuals as well as organization performance. Based on study, it is strongly agreed that there is "higher tendency of reliability and validity in other established emotional intelligence model" (Nelson \& Low, 2011).

There is also a positive relationship between emotional intelligence and leadership through exploratory regression analysis which has consistent finding by (Barling, Slater, \& Kelloway, 2000). This explains that leaders who have high emotional intelligence will use positive emotions to visualize major improvements for the function of an organization. In addition, leaders are able to evaluate their employees accurately by using the information to influence the employees' emotions. This situation is known as effective leadership and it brings 
significant impact towards the performance of employees. Moreover, it is validated that there is "significant relationship between emotional intelligence and leadership performance quality" (Hammett, Hollon, \& Maggard, 2012). The studies observation's result states the positive association between emotional intelligence and leadership as well as employees' performance which is carried out by the United States Air Force military leaders. In a nutshell, evidences above support that there is a positive impact of emotional intelligence on the success of employees towards their work.

\subsection{Leadership in Higher Education}

Leadership in higher education is referred as Academic leadership in which academic leadership plays a vital contribution in higher education (Osseo-Asare, Longbottom, \& Murphy, 2005). Academic leaders should motivate, inspire, and lead their academics towards excellence that falls within the definition of leadership as a process to influence people towards achievement (Howell \& Costley, 2006). According to Gmelch (2002), academic leaders are knitted together with followers and involve in giving directions on completing the given tasks with empowerment as an essential factor. Different institution demands different leadership styles as this institution may have different products or services as well as mission and objectives. Leadership styles may vary between same education institutions and even within the institutions such as different faculty or departments that may have different leadership styles. Ramsden (1998) mentioned that leadership in higher education plays an important role such as leading lecturers in introducing creative approach for effective learning. In addition, leaders play a supportive role in developing a collaborative and visionary in research with the lecturers. An effective leader is someone who inspires and recognize their performance with high interpersonal skills. There is a need for a significant opportunity to explore further about this untapped relationship on academics as a research subject.

The number of higher institutions in Malaysia has expanded enormously in the recent years. Because of the expanding number of universities in Malaysia, academic staffs may confront more issues in their activity as the administrations are confronting serious challenges from competitors. Lately, universities are currently defining new objective to contend with stiff competition from universities just as the academic staff are including with a definitive achieving the desired goals. Hypothetically, the general performance of a higher institution relies on its academic staff and their level of hierarchical duty and fulfillment, which later was considered as significant towards improvement of teaching and learning, supervision and research (Khan et al., 2013; Norshidah 2012). Therefore, understanding academics needs and emotions should be priority for the university achievement and academics excellent job performance is vital in producing human manpower to the nation's development.

Academicians are very crucial personnel in educational institution and their satisfaction and motivation are considered as a primary predetermine for successful teaching learning process towards student's excellence. Academics staff should be respected for their contribution in disseminating knowledge to students and the teaching ability to accomplish the goals to attain the desired objectives. University academics are presently facing many challenges in fulfilling their desired goals. Imparting knowledge to students is not only a core function of a lecturer but also co- currently producing excellence in various fields such as research, collaboration, consultation, and innovative learning. This $21^{\text {st }}$ century knowledge building as well as other key performance indexes has created a huge gap to fill in by the academics and this demanding gap might further affect academics job performance. Presently in Malaysia, the higher learning institutions are restructuring from the traditional educational system to meet "new world" developments keeping in mind the generating knowledge resources and financials (grants) which are among the vital key performance indexes. To achieve such demanding feat and also to have the ability to face challenges in achieving performance index, leadership plays an important role in guiding and supporting. It has been a common remark in Malaysian public universities that academics generally complain about the university management particularly their leader as the leader's decision can be viewed as exclusively directive with lack of understanding.

Furthermore, In March 2020, Universitas 21 (U21) released a finding on 50 countries universities ranking by measuring the education spending plan/resources including grant with expected results, for example, publication, research, and employability among universities graduates. With respect to resources, Malaysia was at eleventh, twelfth, seventeenth (twice), and fifteen places in 2016, 2017, 2018, 2019 and 2020. In which, Malaysia investment higher than other nations, such as, Japan, Korea, and Australia. With respect to universities performance, Malaysia has recorded a diminishing performance, which is in the 39 th, 42 nd and $45^{\text {th }}(2018,2019)$ in a similar period, in fact retaining the position at 45 in 2020 findings. The drop in the U21 ranking of Malaysian universities repudiates with the World University Ranking, "QS" and Times Higher Education World University Ranking (THE) rankings indicator. Therefore, the situation of Malaysian research universities doesn't just mirror the truth of the academician performance as the universities yield doesn't correspond with the ranking, 
creating a desired gap.

\section{Theoretical Views}

\subsection{Attribution Theory}

The concept presentation in this research is deducted from what is known to be as Heider's Attribution Theory 1958. How do we attach meaning to other's behavior, or our own? "Attribution theory deals with how the "social perceiver uses information in order to arrive at causal explanation for events" (Fiske \& Taylor, 1991). The central idea of attribution theory is originally postulated by (Heider, 1958), stating that people behave as "naïve scientists", whereby they quest for the reasons for their own and others' conduct through making and testing hypotheses. According to (Regan, 1978), people feel a need to find "causal explanations for behavior so that they can feel that they are in control with the elements of their environment". Heider (1958) identified people's perception as an important element in an individual; in which Heider (1958) concludes how people perceive each other in interaction. Heider's findings fall within the emotional intelligence-component of perceived emotions. The theory of attribution alludes to how people decipher occasions and how this occasion identifies with their thoughts and conduct. Attribution theory accept that individuals attempts to decide why individuals do what they do and to understand why others do an act and comprehend the attribute of one or more cause to that act. According to Heider (1958) an individual can make ascriptions which concludes that someone is behaving in a certain way because of something about the surrounding that he or she lives in. Based on Heider's findings and Jones (1973) conclusion if someone (S) is aware of the act of another person (P), S will try to determine the meaning of P's action.

This search of meaning typically will take the form of a search for reasons or "reason enough" for $\mathrm{P}$ to have performed an action. Therefore, for this reason (or reasons) it is an intention of action from which the meaning is derived. Perhaps, as subordinates (S) perceived his/her leader's (P) act of ability in perceiving theirs (subordinates) emotions will lead to reasoning and intention of the subordinate's behavior. Moving on, Heider (1958) have made an interesting finding on personal casualty in whom it will be able to be answered why people are trying to do something and there are reasons behind the intentions. Under this circumstance, Heider's personal casualty will be able to support my criterion of intention to perform as the perceiver will derive meaning of the act of others and the state that will influence their intention towards the behavior.

There seems to be an obvious relationship in emerging behavioral theory that associates attributions and emotions. Echoing on (Weiner, 1995) that there have been some efforts to describe how the "links between attributions and emotions" are appropriate to the organizational literature. Relating emotions and attribution, a study by (Tjosvold, 1985) found that leaders who "experienced negative emotions will attribute poor performance" to the absence of effort of their own. Significantly, these negative emotions are possible to affect both leader's behavior and future attributions of employee performance in an undesirable manner (Harvey \& Dasborough, 2006). Therefore, leader's emotion in negative manners does influence the attribution of an employee, leaving an understanding that inability of leaders in perceiving subordinates' emotion as part of negative emotions ability within them. Consistently, Dasborough and Ashkanasy, (2002) added that leader's display of emotions are an important impression management tactic" that can induce and attribute emotional reactions in their members. In view of this and relating it to transformational leadership, we can argue that positive emotions within leaders spurs emotional "attribution" reactions among the subordinates leading to desired transformational leadership and if its vice versa than it leads to perception of pseudo-transformational leadership. In addition, emotional perception deficits may lead individuals to make erroneous attributions about other people in social interaction (Garcia-Sancho, Salguero, \& Fernandez-Berrocal, 2015).

Therefore, attributions can lead to the behavior and explain the outcomes of a behavior. Much of the work on attribution theory assumes and demonstrates that discrete emotions and affective states mediate the relationship between attributions and behaviors (Harvey, Martinko, \& Borkowski, 2007). Interestingly existing research has been done a little to empirically investigate the nature and power of influences in the attribution especially on leader's emotional behavior towards subordinates levying a potentially interesting area for research. Standing, Standing, Kordt, and Standing (2016) related the issues of completing projects in IT by stating that there is still limited research on the emotional and behavioral of individuals towards project success or failure. Standing et al. (2016) further explained that this research's limitations are the "individual differences and attribution style which indicates the way every individual explains their own behavior. Therefore, this can lead to an understanding that subordinate's own success or failure is based on their perception towards their leader's behavior. (Davison \& Smothers, 2015) referred that the failure of new ventures are typically attributed to internal factors (e.g. poor management) rather than external factors. 
As align with Davison and Smothers (2015) attribution theory, which has been somewhat underutilized in organizational research (Harvey \& Weary, 1985) provides insight into this problem. Whilst Weiner's attribution model of achievement motivation is also recognized in aiming for self-esteem and achievement but notably for integrating attribution theory with expectancy of success and emotions. This integration has enabled researchers to "understand the effects of attributions on the dynamics of behavior" (Anderson \& Weiner, 1992). Attribution theory can provide an appropriate theoretical lens in studying the relationship between emotional intelligence, idealized influence and intent to perform especially on the concept of perceived emotional intelligence by the subordinates. In sum, according to Hareli (2014), it appears that "individuals use their naïve understanding of the linkages between causal attributions and emotions in order to navigate their social world and this inference drawn from others' emotions and influences others' emotions". Moreover, the study of emotions and influence within attribution construct or more generally related information is limited and neglected. In addition, growing body of studies in recent years has studied the use of naïve knowledge on cognition-emotion in which emotion acts as a core element. However, Hareli (2014) said that, relationship between attributions and emotions as discussed by Weiner (2014) exist in the context of positive or negative perception and is still warranted for further research in examining "if and how their understanding is used". It has been suggested that both drawing inferences from others' emotions and influencing their emotions are based on an explicit understanding of the linkages between appraisals and emotions where people use this knowledge to draw inferences in order to influence other's emotions (Hareli, 2014; de Melo, Carnevale, Read, \& Gratch, 2014; Hareli \& Hess, 2010; Weiner, 1987).

Theory Planned Behaviour (TPB) gives little attention to emotions as well as the affective response is a form of evaluation toward an intention and the behavior. Vollenwyder, Iten, Brühlmann, Opwis, and Mekler (2019) further asserted that while TPB outlines how salient beliefs may determine the intention and actual performance of a behavior, it does not specify the origins of these beliefs, as such, this current study inferred the origins of beliefs is the leaders' emotional intelligence as well as leaders' idealized influence. Sniehotta, Presseau, and Araújo-Soares $(2014$, p. 2) added that "[TPB] theory has been criticized for its exclusive focus on rational reasoning, excluding unconscious influences on behavior “. In other words, TPB does not inevitably accept phenomenon in a planned way because people often do things in an unplanned manner too (Hossain, Dwivedi, Chan, Standing, \& Olanrewaju, 2018; Piçarra \& Giger, 2018; Park, Keil, Bock, \& Kim, 2015). Therefore, this study has adapted attribution theory as it undertakes and exhibits that emotions and affective do intercede attributions and behaviors (Becker, Conroy, Djurdjevic, \& Gross, 2018; Harvey, Martinko, \& Borkowski, 2007). In addition, attribution theory can explain the formation of emotional reactions that influence attitudes, as well as antecedents of attitudes (Folkes, 1988; Glaser \& Salovey, 1998; Weiner, 1985; Ajzen \& Fishbein, 2005). As such as mentioned by Weiner (1985) and Matthes, Knoll, and Von Sikorski (2017) that emotional reaction and behavior is formed base on attribution that forms the causal relationship. As early as the 1970s, attribution theory was used as the leadership perception model (Mitchell, Larson, \& Green, 1977; Pfeffer, 1977). Unfortunately, existing research has been done a little to empirically investigate attribution theory especially on academic leader's emotional behavior towards subordinates' intentions.

\subsection{Transformational Leadership}

Transformational leadership alludes to "a style of leadership that changes followers to transcend their personal responsibility by influence their spirit, beliefs, interests, and qualities, inspiring them to perform better than at first expected" (Pieterse, Knippenberg, Schippers, \& Stam, 2010, p. 610). Transformational leadership can be portrayed utilizing a four-dimensional model involved idealized influence, inspiration, individual consideration and intellectual (Bass \& Avolio, 1994). As per Bass (1985), transformational leadership includes a social exchange process that is not quite the same as any material or monetary exchange engaged with value-based leadership (Pillai, Schriesheim, \& Williams, 1999). At the point when followers experience leaders' kindheartedness (i.e., care and worry) just as sentiments of being esteemed in a relationship, they will reciprocate regarding their emotional connection, subsequently creating influence based trust in their leaders (Colquitt, Lepine, Piccolo, Zapata and Rich, (2012); Lapidot, Kark and Shamir, (2007). Caillier and Sa, (2016) referenced that transformational leaders tries to persuade employees by invigorating them mentally, furnishing them with individualized consideration, provoking them to accomplish elevated expectations and articulating a convincing vision. Also, transformational leaders are "speculated to accomplish better outcomes with their followers compared with other leadership styles" (Bass \& Riggio, 2006).

Transformational leadership and emotional intelligence share an emotional component and are often discussed in conjunction with one another (Potter, Egbelakin, Phipps, \& Balaei, 2018). Bryant and Williams (2018) stated that a quintessential component of a transformational leader is emotional intelligence, in which research indicates 
that transformational leadership skills correlate with emotional intelligence. Furthermore, Chan, Omar, Ramlan, Ahmad, Zaman, and Idrus (2018) and Matjie (2018) state domains of transformational leadership and emotional intelligence need to be explored such as idealized influence in this study. Charisma is shown by leaders who go about as good examples, making a feeling of recognizable proof with a common vision and feeling of pride and certainty by overcoming deterrents. This construct is otherwise called an idealized influence and can be separated further into two sub factors -attributes and behavior (Gilbert, Horsman, \& Kelloway, 2016). "Emotion perception ability in leaders will facilitate high-quality leader-member relationship and lead to job performance and satisfaction" (Rubin, Robert, David, \& Bommer, 2005). Ability to perceive emotion is strongly correlated with transformational leadership behavior. However, it is moderate for the other aspects of leadership skills such as goal setting skills, intrapersonal skills and extraversion personality trait (Rubin et al., 2005). Therefore, a transformational leader should equip him/her with other aspects of emotional intelligence and skills to maximize the effectiveness of emotional perception. Studies show that emotional perception can predict several components which are important for transformational leadership. Research shows that people who have got high emotion perception have got higher motivation to lead. In a teamwork or organizational context, emotional perception is needed for a leader to have effective communication with their subordinates which leads to job performance. It can increase the leadership self-efficacy and further improve the motivation to lead by having job satisfaction yielded in job performance (Krishnakumar \& Hopkins, 2014).

\section{Hypotheses Development}

\subsection{Relationship Between Emotional Intelligence and Intention to Perform}

Emotional intelligence can be defined as the ability to accurately identify and understand one's own emotional reactions and others (Muyia \& Kacirek, 2009). Many scholars have agreed that emotional intelligence is vital in leadership and leader's achievement as well as their development (Nelson \& Low, 2011; Shuck \& Herd, 2012; Yukl \& Mahsud, 2010). The combination between emotional intelligence and leadership are catalyst towards employees' performance, relationship, and successful organizations. Both construct help leaders in planning, making decision, solve complex problems and time management. Above all is the adapting their behaviour to the situation and manage crisis. Bass \& Stogdill, (1990) and Krishnan, (2001) mentioned that superior performance is possible through stimulating and motivating employees to higher level of performance through leadership concept. (Shockley et al., 2012) in their Meta-Analytic investigation of the relationship between state affect, discrete emotions, and job performance have argued that rather than formulating predictions concerning numerous discrete emotions to multiple dimensions of job performance, the researcher evaluate these relationships in a descriptive manner in which examine the unique relationship of each emotion to each performance dimension, the relative strengths of these associations, and how these relationships compare to the link between dimensional affect and performance. Researchers have aggressively examined the fact of how emotional intelligence helps to attain desire outcome or performance. Consequently, Fay \& Sonnentag (2012) added that job performance acknowledges that people do not perform at a constant level but that there are fluctuations in performance, as such this fluctuations in performance is due to the uncertainty in their intention to perform. Thus, the following hypothesis is proposed:

H1. Emotional intelligence in leaders will be positively influence intention to perform.

\subsection{Relationship Between Emotional Intelligence and Idealized Influence}

Originally, Emotional Intelligence is defined by Salovey and Mayer, (1990), "as the intellectual processes in recognizing, using, understanding, and managing of individual's own and others' emotional and use this information to guide one's thinking and actions. As a result, leaders with high emotional intelligence will maintain strong relation with others as well as recognized by subordinate. Leadership abilities in emotional intelligence will be a catalyst in leader's influence towards their subordinates. Influence is a very important and crucial factor, the most important managerial instrument to motivate and manage people effectively. Influence can play a positive or negative role. Bringing in into the discussion on idealized influence and it is strongly believing that leader with idealized influence behaviours in an organization might impact towards employees' increased trust in the leader and higher overall performance. Yukl (1999) argues that this leadership model omits some important behaviours known to be associated with effective leadership, such as influence behaviours. Thus, the following hypothesis is proposed:

H2. Emotional intelligence is positively related with idealized influence

\subsection{Relationship Between Idealized Influence and Intention to Perform}

Contemporary leadership theories are introduced that demonstrate the centrality of emotional skills for effective 
leadership and charismatic leadership. Example for effective leadership is transformational leadership which the research has been carried out by (Bass, 1985). Nevertheless, charismatic leadership is examined by prior researchers such as (Conger \& Kanungo, 1998) as well as (House, 1977). Under this theme of leadership, it is more emphasizes on leader's mood and emotional displays which will bring significant influence towards collective tone and mood of the employees (George \& Brief, 1992). But Burns (1978) stated that transformational leaders inspire their followers to look beyond self-interest and collective purpose. Apart from that, Judge and Piccolo (2004) supported the relationship between idealized influence leadership and leader effectiveness by meta-analyses. The author found overall corrected of 0.71 correlations for idealized influence and effectiveness of leadership. The path coefficient was relatively high, and this demonstrates that employees are having similar behaviors with their leaders. Therefore, there is a positive relationship between idealized influence leadership and effectiveness of leadership, which in turn lead to an increase in employees' job performance due to high self-efficacy (Russell, 2013). Building from Hofmann et al. (1992), Sonnentag and Frese, (2012) and Dalal et al. (2014) that variances exits in individual towards job performance and further understanding the antecedents towards performance is vital. Therefore, understanding and acknowledging job performance is the not the solution of a survival of an organization but what varies and contributes to the job performance itself is a 'survival' and worth researching. (Nimon et al., 2011) precisely identify that intentions have proved to be far better predictors of resultant desired behaviors as compared to others outcome measures. Thus, the following hypothesis is proposed:

H3. Idealized influence is positively related to intention to perform.

\subsection{Mediating Role of Idealized Influence on the Relationship Between Emotional Intelligence and Intention to Perform}

Idealized influence is proposed as the mediator between emotional intelligence and intention to perform between leaders' and subordinate. Theory of Reasoned Action (TRA) proposed by (Fishbein \& Ajzen, 1975) explains behaviour based on an individual's expectations of outcomes. The inclusion of subjective norms in the TRA represents significant additions to take account of the elements of social influence in social environment. Social influence is defined as the degree to which an individual appreciates the interests of others and remain that he or she will need to use the new system. Bringing in the great philosopher Confucius as a role model to his followers and his followers identified closely with him, emulating his behaviours. Confucius demonstrated virtues of benevolence "[ren], righteousness [yi ], rituals [li ], wisdom [zhi ], trustworthiness [xin ], fortitude [yong ], and frugality [jian ]" and through his actions he influenced them (Analects, 4, p. 25). At the end of the day, leaders who have ethics are probably gain greater supports from their subordinates. Confucius as a "transformational leader", convinced through exchange, cooperation and strengthening (Bass, 1985). Confucius stated, "With respect to the compassionate, while they need to be set up themselves, they set up others. While they need to succeed themselves, they help other people to succeed (Analects, 6, p. 30).

Associating with idealized influence and one's emotion ability is vital in succeeding Confucius leader's virtues. As explained by (Erkutlu \& Chafra, 2012) that leaders would have significant levels of emotional intelligence are probably going to perceive subordinates' needs, look into them and react to changes in their emotional states. Therefore, the reciprocity interaction between leaders and subordinate's confluence behaviour response with idealized influence of inspiring pride in others for being connected with the leaders, urging employees to go past their personal circumstance to assist group or organization and so forth. Menon (2014) observed that there is higher tendency to have significant and positive relationship with idealized influence leadership behaviours and job satisfaction. In a situation of high overall job satisfaction, perform better and higher impact on higher job performance. Emotional intelligence is an ability of an individual in recognizing one's emotion and others, raising the question whether abilities of an individual particularly a leader's ability can influence the intention of subordinates towards intention to perform. Particularly relevant to the inclusion of emotional intelligence's characteristic that it's arises the feelings to motivate, plan and attain the individual performance in which defining the intention. The TPB Ajzen (1991) is a psychological model, which has become highly influential in the past decade predicting individual behaviour with motivational intentions, which are themselves determined by antecedents. Based on TPB theory with influence concept and emotional intelligence ability would in turn influence employee's intentions, which, finally, would impact the employee's behaviour. Leaders motivate through their emotion's ability and thus leaders emotion ability is a motivation leading to the predetermine behaviour of intention to perform. Thus, the following hypothesis is proposed:

H4. Idealized influence will mediate the relationship between emotional intelligence and intention to perform. 


\section{Conclusion}

Intention to perform is conceptualized as an important construct prior for a job performance in the literature but it has not been studied comprehensively with emotional intelligence. The dominant characteristic of intention to perform with emotional intelligence can be effectively addressed by attribution theory originated from Heider (1958) which presumes that there is despite restricted research on the emotional and behavior which has been to some degree underutilized in research. Among many constructs studied towards various types of intention, emotional intelligence has received the least attention towards intention to perform. Therefore, it is more distinctive informative to examine these two relationships as they can provide a new epistemology in the study. Literature suggests that emotional intelligence can be viewed through its own emotional intelligence model developed by Salovey \& Meyer (1990). Thus, empirical examination of emotional intelligence and idealized influence are mediating mechanisms in the intention to perform relationship which will expand to new epistemology.

\section{Acknowledgements}

This work was supported by University Tunku Abdul Rahman Research Fund (UTARRF) grant funded by University Tunku Abdul Rahman (No: 6200/G43/2018).

\section{References}

Abraham, R. (2004). Emotional competence as antecedent to performance: A contingency framework. Genetic, $\begin{array}{lllll}\text { Social, and General Psychology } & \text { Monographs, 130(2), }\end{array}$ https://doi.org/10.3200/MONO.130.2.117-145

Ajzen, I. (1991). The theory of planned behavior. Organizational behavior and human decision processes, 50(2), 179-211. https://doi.org/10.1016/0749-5978(91)90020-T

Ajzen, I., \& Fishbein, M. (1975). Belief, attitude, intention and behavior: An introduction to theory and research: Reading. MA: Addison-Wesley.

Alston, B. A. (2009). An examination of the relationship between emotional intelligence and leadership practices. Nova Southeastern University.

Anderson, C. A., \& Weiner, B. (1992). Attribution and attributional processes in personality. Modern personality psychology: Critical reviews and new directions, 295-324.

Antonakis, J., Avolio, B. J., \& Sivasubramaniam, N. (2003). Context and Leadership: An Examination of the Nine-Factor Full-Range Leadership Theory Using the Multifactor Leadership Questionnaire. The Leadership Quarterly, 14(3), 261-295. https://doi.org/10.1016/S1048-9843(03)00030-4

Ariyabuddhiphongs, V., \& Kahn, S. I. (2017). Transformational leadership and turnover intention: The mediating effects of trust and job performance on café employees in Thailand. Journal of Human Resources in Hospitality \& Tourism, 16(2), 215-233. https://doi.org/10.1080/15332845.2016.1202730

Austin, E. J. (2004). An investigation of the relationship between trait emotional intelligence and emotional task $\begin{array}{llrr}\text { performance. Personality and Individual Differences, } 36, & \text { 1855-1864. }\end{array}$ https://doi.org/10.1016/j.paid.2003.07.006

Avolio, B. J., \& Locke, E. E. (2002). Contrasting different philosophies of leader motivation: Altruism versus egoism. The Leadership Quarterly, 13(2), 169-191. https://doi.org/10.1016/S1048-9843(02)00094-2

Barling, J., Slater, F., \& Kevin Kelloway, E. (2000). Transformational leadership and emotional intelligence: An exploratory study. Leadership \& Organization Development Journal, 21(3), 157-161. https://doi.org/10.1108/01437730010325040

Bass, B. M. (1985). Leadership and performance beyond expectations. Free Press; Collier Macmillan.

Bass, B. M., \& Avolio, B. J. (1994). Shatter the glass ceiling: Women may make better managers. Human resource management, 33(4), 549-560. https://doi.org/10.1002/hrm.3930330405

Bass, B. M., \& Riggio, R. E. (2006). Transformational leadership. Psychology Press. https://doi.org/10.4324/9781410617095

Bass, B. M., \& Stogdill, R. M. (1990). Handbook of leadership (Vol. 11). New York: Free Press.

Becker, W., Conroy, S., Djurdjevic, E., \& Gross, M. (2018). Crying is in the eyes of the beholder: An attribution theory framework of crying at work. Emotion Review, 10(2), 125-137. https://doi.org/10.1177/1754073917706766 
Bryant, S., \& Williams, F. H. (2018). Do transformational leadership and growth mindset impact safety for wilderness work crews? Journal of Leadership and Management, 2(12), 1-8.

Burns, J. M. (1978). Leadership. NY: Harper \& Row.

Caillier, J. G., \& Sa, Y. (2017). Do transformational-oriented leadership and transactional-oriented leadership have an impact on whistle-blowing attitudes? A longitudinal examination conducted in US federal agencies. Public Management Review, 19(4), 406-422. https://doi.org/10.1080/14719037.2016.1177109

Carrera, P., Caballero, A., \& Munoz, D. (2012). Future-oriented emotions in the prediction of binge-drinking intention and expectation: The role of anticipated and anticipatory emotions. Scandinavian journal of psychology, 53(3), 273-279. https://doi.org/10.1111/j.1467-9450.2012.00948.x

Carver, C. S. (1998). Resilience and thriving: Issues, models, and linkages. Journal of social issues, 54(2), 245-266. https://doi.org/10.1111/j.1540-4560.1998.tb01217.x

Chan, S. W., Omar, S. S., Ramlan, R., Ahmad, M. F., Zaman, I., \& Idrus, N. (2018). Emotional intelligence and transformational leadership among managers in manufacturing companies. International Journal of Engineering and Technology, 7(3), 1-4. https://doi.org/10.14419/ijet.v7i3.21.17083

Charbonneau, D. (2004). Influence tactics and perceptions of transformational leadership. Leadership \& Organization Development Journal, 25(7), 565-576. https://doi.org/10.1108/01437730410561459

Colquitt, J. A., LePine, J. A., Piccolo, R. F., Zapata, C. P., \& Rich, B. L. (2012). Explaining the justiceperformance relationship: Trust as exchange deepener or trust as uncertainty reducer?. Journal of Applied Psychology, 97, 1-15. https://doi.org/10.1037/a0025208

Conger, J. A., \& Kanungo, R. N. (1998). Charismatic leadership in organizations. Sage Publications.

Dalal, R. S., Bhave, D. P., \& Fiset, J. (2014). Within-person variability in job performance a theoretical review and research agenda. Journal of Management. https://doi.org/10.1177/0149206314532691

Dasborough, M. T., \& Ashkanasy, N. M. (2002). Emotion and attribution of intentionality in leader-member relationships. The Leadership Quarterly, 13(5), 615-634. https://doi.org/10.1016/S1048-9843(02)00147-9

Davison, H. K., \& Smothers, J. (2015). How Theory X style of management arose from a fundamental attribution error. J. of Management History, 21(2), 210-231. https://doi.org/10.1108/JMH-03-2014-0073

Day, A. L., \& Carroll, S. A. (2004). Using an ability-based measure of emotional intelligence to predict individual performance, group performance, and group citizenship behaviors. Personality and Individual Differences, 36, 1443-1458. https://doi.org/10.1016/S0191-8869(03)00240-X

de Melo, C. M, Carnevale, P. J., Read, S. J., \& Gratch, J. (2014). Reading people's minds from emotion expressions in interdependent decision making. Journal of personality and social psychology, 106(1), 73. https://doi.org/10.1037/a0034251

Deshwal, P. (2016). Customer experience quality and demographic variables (age, gender, education level, and family income) in retail stores. International Journal of Retail \& Distribution Management. https://doi.org/10.1108/IJRDM-03-2016-0031

Dionne, S. D., Yammarino, F. J., Atwater, L. E., \& Spangler, W. D. (2004). Transformational leadership and team performance. Journal of Organizational Change Management, 17(2), 177-193. https://doi.org/10.1108/09534810410530601

Eliophotou Menon, M. (2014). The relationship between transformational leadership, perceived leader effectiveness and teachers' job satisfaction. Journal of Educational Administration, 52(4), 509-528. https://doi.org/10.1108/JEA-01-2013-0014

Erkutlu, H., \& Chafra, J. (2012). The impact of team empowerment on proactivity: The moderating roles of leader's emotional intelligence and proactive personality. Journal of health organization and management, 26(5), 560-577. https://doi.org/10.1108/14777261211256918

Fay, D., \& Sonnentag, S. (2012). Within-person fluctuations of proactive behavior: How affect and experienced competence regulate work behavior. Human Performance, 25(1), 72-93. https://doi.org/10.1080/08959285.2011.631647

Fishbein, M., \& Ajzen, I. (1975). Belief, Attitude, Intention, and Behaviour. Addison-Wesley Pub. Co., Reading, Mass.

Fiske, S. T., \& Taylor, S. E. (1991). Social cognition (2nd ed.). NY: McGraw-Hill. Personnel Review, 42(5), 
$552-572$.

Folkes, V. S. (1988). Recent attribution research in consumer behavior: A review and new directions. Journal of Consumer Research, 14(4), 548-565. https://doi.org/10.1086/209135

Frings, D., Melichar, L., \& Albery, I. P. (2016). Implicit and explicit drinker identities interactively predict in-the-moment alcohol placebo consumption. Addictive Behaviors Reports, 3, 86-91. https://doi.org/10.1016/j.abrep.2016.04.002

Garcia-Sancho, E., Salguero, J. M., \& Fernandez-Berrocal, P. (2015). Deficits in facial affect recognition and aggression: A systematic review. Ansiedad y Estres, 21, 1-20.

George, J. M., \& Brief, A. P. (1992). Feeling good-doing good: A conceptual analysis of the mood at work-organizational spontaneity relationship. Psychological Bulletin, 112(2), 310. https://doi.org/10.1037/0033-2909.112.2.310

Gilbert, S., Horsman, P., \& Kelloway, E. K. (2016). The Motivation for Transformational Leadership Scale: An examination of the factor structure and initial tests. Leadership \& Organization Development Journal, 37(2), 158-180. https://doi.org/10.1108/LODJ-05-2014-0086

Glaser, J., \& Salovey, P. (1998). Affect in electoral politics. Personality and Social Psychology Review, 2(3), 156-172. https://doi.org/10.1207/s15327957pspr0203_1

Gmelch, W. H. (2002). The Call for Department Leaders.

Gomes, A. R., Gonçalves, A. M., Maddux, J. E., \& Carneiro, L. (2017). The intention-behaviour gap: An empirical examination of an integrative perspective to explain exercise behaviour. International Journal of Sport and Exercise Psychology, 1-15. https://doi.org/10.1080/1612197X.2017.1321030

Hallikainen, H., Paesbrugghe, B., Laukkanen, T., Rangarajan, D., \& Gabrielsson, M. (2017, January). How Individual Technology Propensities and Organizational Culture Influence B2B Customer's Behavioral Intention to Use Digital Services at Work?. In Proceedings of the 50th Hawaii International Conference on System Sciences. https://doi.org/10.24251/HICSS.2017.552

Hammett, R., Hollon, C., \& Maggard, P. (2012). Professional military education (PME) in the USAF SOS leadership course: Incorporating emotional intelligence. The International Journal of Transformative Emotional Intelligence, 1, 73-96.

Hareli, S. (2014). Making sense of the social world and influencing it by using a naïve attribution theory of emotions. Emotion Review, 6(4), 336-343. https://doi.org/10.1177/1754073914534501

Hareli, S., \& Hess, U. (2010). What emotional reactions can tell us about the nature of others: An appraisal perspective on person perception. Cognition and Emotion, 24(1), 128-140. https://doi.org/10.1080/02699930802613828

Harvey, J. H., \& Weary, G. (1985). Attribution: Basic issues and applications. Academic Press.

Harvey, P., \& Dasborough, M. T. (2006). Consequences of employee attributions in the workplace: The role of emotional intelligence. Psicothema, 18(Suplemento), 145-151.

Harvey, P., Martinko, M. J., \& Borkowski, N. (2007). Unethical behavior among physicians and students: Testing an attributional and emotional framework. Paper presented at the Academy of Management Conference, Philadelphia, PA.

Hatfield, D. D. (2009). Relationships between emotional intelligence competencies and transformational leadership skills: US government civil servant leaders. University of Phoenix.

Heider, F. (1958). Interpersonal relations. New York: Wiley. https://doi.org/10.1037/10628-000

Hofmann, D. A, Jacobs, R., \& Gerras, S. J. (1992). Mapping individual performance over time. Journal of Applied Psychology, 77(2), 185-195. https://doi.org/10.1037/0021-9010.77.2.185

Hossain, M. A., Dwivedi, Y. K., Chan, C., Standing, C., \& Olanrewaju, A.-S. (2018). Sharing political content in online social media: A planned and unplanned behaviour approach. Information Systems Frontiers, 20(3), 485-501. https://doi.org/10.1007/s10796-017-9820-9

House, R. J. (1977). A 1976 theory of charismatic leadership. Leadership: The cutting edge, 189-207.

Howell, J. P., \& Costley, D. L. (2006). Understanding Behaviors for Effective Leadership (2nd ed.). Pearson Prentice Hall, Englewood Cliffs, NJ. 
Ingersoll, R. M. (2001). Teacher Turnover and Teacher Shortages: An Organizational Analysis. American Educational Research Journal, 38(3), 499-534. https://doi.org/10.3102/00028312038003499

James, K. T., \& Arroba, T. (2005). Reading and Carrying A Framework for Learning about Emotion and Emotionality in Organizational Systems as a Core Aspect of Leadership Development. Management Learning, 36(3), 299-316. https://doi.org/10.1177/1350507605055348

Jones, S. C. (1973). Self-and interpersonal evaluations: Esteem theories versus consistency theories. Psychological bulletin, 79(3), 185. https://doi.org/10.1037/h0033957

Joseph, D. L., \& Newman, D. A. (2010). Emotional intelligence: An integrative meta-analysis and cascading model. Journal of Applied Psychology, 95, 54-78. https://doi.org/10.1037/a0017286

Kark, R., Waismel-Manor, R., \& Shamir, B. (2012). Does valuing androgyny and femininity lead to a female advantage? The relationship between gender-role, transformational leadership and identification. The Leadership Quarterly, 23(3), 620-640. https://doi.org/10.1016/j.leaqua.2011.12.012

Khairunneezam, M. N. (2011). Work-life balance and intention to leave among academics in Malaysia public higher education institutions. International Journal of Business and Social Science, 2(11), 240-248.

Khan, I., Nawaz, A., Khan, F., Khan, H., Khan, S., \& Kundi, A. H. (2013). The Impact of Organizational Commitment and Job Satisfaction 492 L. Tahir et al. Downloaded by [UQ Library] at 15:44 13 November 2014 on the ITL of Academicians in HEIs of Developing Countries like Pakistan. Industrial Engineering Letters, 3(9), 18-26.

Kim, H. J., \& Park, D. (2016). The effects of workplace bullying on turnover intention in hospital nurses. Journal of Digital Convergence, 14(1), 241-252. https://doi.org/10.14400/JDC.2016.14.1.241

Kim, S. Y., \& Fernandez, S. (2017). Employee empowerment and turnover intention in the US federal bureaucracy. The American Review of Public Administration, 47(1), 4-22. https://doi.org/10.1177/0275074015583712

Klass, G. (2009). Intent to contract. Virginia Law Review, 1437-1503.

Knapp, J. R., Smith, B. R., \& Sprinkle, T. A. (2017). Is It the Job or the Support? Examining Structural and Relational Predictors of Job Satisfaction and Turnover Intention for Nonprofit Employees. Nonprofit and Voluntary Sector Quarterly. https://doi.org/10.1177/0899764016685859

Kouzes, J. M., \& Posner, B. Z. (2003). The Leadership Practices Inventory (LPI): Participant's Workbook (Vol. 47). John Wiley \& Sons.

Krishnakumar, S., \& Hopkins, K. (2014). The role of emotion perception ability in motivation to lead. Management Research Review, 37(4), 334-347. https://doi.org/10.1108/MRR-07-2012-0161

Lam, L. T., \& Kirby, S. L. (2002). Is emotional intelligence an advantage? An exploration of the impact of emotional and general intelligence on individual performance. Journal of Social Psychology, 142, 133-143. https://doi.org/10.1080/00224540209603891

Lannoo, S., \& Verhofstadt, E. (2016). What drives the drivers? Predicting turnover intentions in the Belgian bus and coach industry. Transportation Research Part A: Policy and Practice, 91, 251-259. https://doi.org/10.1016/j.tra.2016.06.024

Lantos, G. (2011). Consumer Behavior in Action. M.E. Sharpe, Armonk, N.Y.

Law, K. S., Wong, C., \& Song, L. J. (2004). The construct and criteria validity of emotional intelligence and its potential utility for management studies. Journal of Applied Psychology, 89, 483-496. https://doi.org/10.1037/0021-9010.89.3.483

Law, K. S., Wong, C., Huang, G. H., \& Li, X. (2008). The effects of emotional intelligence on job performance and life satisfaction for the research and development scientists in China. Asia Pacific Journal of Management, 25, 51-69. https://doi.org/10.1007/s10490-007-9062-3

Lee, H.-W., \& Liu, C.-H. (2007). An examination of factors affecting repatriates' turnover intentions. International Journal of manpower, 28(2), 122-134. https://doi.org/10.1108/01437720710747956

Lee, Y. H., \& Chelladurai, P. (2018). Emotional intelligence, emotional labor, coach burnour, job satisfaction, and turnover intention in sport leadership. European Sport Management Quarterly, 18(4), 393-412. https://doi.org/10.1080/16184742.2017.1406971

Li, J. J., Kim, W. G., \& Zhao, X. R. (2017). Multilevel model of management support and casino employee 
turnover intention. Tourism Management, 59, 193-204. https://doi.org/10.1016/j.tourman.2016.08.006

Malhotra, R., \& Kansal, R. (2017). Transformational leadership: An outcome of emotional intelligence. International Journal of Scientific Research and Education, 5(6), 6686-6691.

Matjie, M. (2018). Emotional intelligence and organizational leadership effectiveness in South Africa. In A. Farazmand (Ed.), Global encyclopedia of public administration, public policy, and governance (pp. 1-5). New York, NY: Springer International Publishing. https://doi.org/10.1007/978-3-319-31816-5_3494-1

Matthes, J., Knoll, J., \& von Sikorski, C. (2017). The "Spiral of Silence" revisited: A meta-analysis on the relationship between perceptions of opinion support and political opinion expression. Communication Research, 45(1), 3-33. https://doi.org/10.1177/0093650217745429

Miao, C., Humphrey, R. H., \& Qian, S. (2018). Emotional intelligence and authentic leadership: A meta-analysis. Leadership \& Organization Development J., 39(5), 679-690. https://doi.org/10.1108/LODJ-02-2018-0066

Mitchell, T. R., Larson, J. R., \& Green, S. G. (1977). Leader behavior, situational moderators, and group performance: An attributional analysis. Organizational Behavior and Human Performance, 18(2), $254-268$. https://doi.org/10.1016/0030-5073(77)90030-7

Moons, I., \& De Pelsmacker, P. (2015). An extended decomposed theory of planned behaviour to predict the usage intention of the electric car: A multi-group comparison. Sustainability, 7(5), 6212-6245. https://doi.org/10.3390/su7056212

Moynihan, D. P., Pandey, S. K., \& Wright, B. E. (2012). Setting the Table: How Transformational Leadership Fosters Performance Information Use. Journal of Public Administration Research and Theory, 22(1), 143-164. https://doi.org/10.1093/jopart/mur024

Muyia, H. M., \& Kacirek, K. (2009). An empirical study of a leadership development training program and its impact on emotional intelligence quotient (EQ) scores. Advances in Developing Human Resources, 11(6), 703-718. https://doi.org/10.1177/1523422309360844

Nelson, D. B., \& Low, G. R. (2011). Emotional intelligence. Boston: Prentice Hall.

Nimon, K., Zigarmi, D., Houson, D., Witt, D., \& Diehl, J. (2011). The work cognition inventory: Initial evidence of construct validity. Human Resource Development Quarterly, 22(1), 7-35. https://doi.org/10.1002/hrdq.20064

Norshidah, N. (2012). The Influence of Leadership Behavior and Organizational Commitment on Organizational Readiness for change in a Higher Learning Institution. Asia Pacific Educational Review, 13, 239-249. https://doi.org/10.1007/s12564-011-9200-y

Osseo-Asare, A. E., Longbottom, D., \& Murphy, W. D. (2005). Leadership best practices for sustaining quality in UK higher education from the perspective of the EFQM Excellence Model. Quality Assurance in Education, 13(2), 148-170. https://doi.org/10.1108/09684880510594391

Ouyang, Y., Tang, C., Rong, W., Zhang, L., Yin, C., \& Xiong, Z. (2017, January). Task-technology Fit Aware Expectation-confirmation Model towards Understanding of MOOCs Continued Usage Intention. In Proceedings of the 50th Hawaii International Conference on System Sciences. https://doi.org/10.24251/HICSS.2017.020

Panchal, A. R., Fishman, J., Camp-Rogers, T., Starodub, R., \& Merchant, R. M. (2015). An "Intention-Focused" paradigm for improving bystander CPR performance. Resuscitation, 88, $48-51$. ttps://doi.org/10.1016/j.resuscitation.2014.12.006

Park, E., \& Ohm, J. (2014). Factors influencing the public intention to use renewable energy technologies in South Korea: Effects of the Fukushima nuclear accident. Energy Policy, 65, $198-211$. https://doi.org/10.1016/j.enpol.2013.10.037

Park, S. C., Keil, M., Bock, G.-W., \& Kim, J. U. (2015). Winner's regret in online C2C Auctions: An automatic thinking perspective. Information Systems Journal, 26(6), 613-640. https://doi.org/10.1111/isj.12075

Pfeffer, J. (1977). The ambiguity of leadership. The Academy of Management Review, 2(1), $104-112$. https://doi.org/10.5465/amr.1977.4409175

Piçarra, N., \& Giger, J.-C. (2018). Predicting intention to work with social robots at anticipation stage: Assessing the role of behavioral desire and anticipated emotions. Computers in Human Behavior, 86, 129-146. https://doi.org/10.1016/j.chb.2018.04.026 
Pieterse, A. N., Knippenberg, D. V., Schippers, M., \& Stam, D. (2010). Transformational and transactional leadership and innovative behavior: The moderating role of psychological empowerment. Journal of Organizational Behavior, 31, 609-623. https://doi.org/10.1002/job.650

Pillai, R., Schriesheim, C. A., \& Williams, E. S. (1999). Fairness perceptions and trust as mediators for transformational and transactional leadership: A two-sample study. Journal of Management, 25, 897-933. https://doi.org/10.1177/014920639902500606

Potter, E. M., Egbelakin, T., Phipps, R., \& Balaei, B. (2018). Emotional intelligence and transformational leadership behaviours of construction project managers. Journal of Financial Management of Property and Construction, 23(1), 73-89. https://doi.org/10.1108/JFMPC-01-2017-0004

Pradhan, S., \& Jena, L. K. (2018). Emotional intelligence as a moderator in abusive supervision-intention to quit relationship among Indian healthcare professionals. Asia-Pacific Journal of Business Administration, 10(1), 35-49. https://doi.org/10.1108/APJBA-09-2017-0089

Pritchard, R. D. (1976). Motivation theory in industrial and organizational psychology. Handbook of industrial and organizational psychology, 63-130.

Purvanova, R. K., \& Bono, J. E. (2009). Transformational leadership in context: Face-to-face and virtual teams. The Leadership Quarterly, 20(3), 343-357. https://doi.org/10.1016/j.leaqua.2009.03.004

Raman, G., Peng, N. L., \& Chen, I. (2020). The mediating effect of Leaders' Idealized Influence on the Relationship between Leaders' Emotional Intelligence and Intention to Perform among Academics in Malaysian Research Universities: Gender as a Moderator. Journal of Contemporary Issues and Thought, 10(1), 1-16.

Ramsden, P. (1998). Managing the effective university. Higher education research \& development, 17(3), 347-370. https://doi.org/10.1080/0729436980170307

Rawls, J. (1999). A Theory of Justice (rev. ed.). Cambridge, MA: Belknap.

Ridza, N. I. A. M., \& Muda, W. H. N. W. (2014). Leadership of Technical Students through Co-curriculum Activities in University. Journal of Management, 2(2), 39-43.

Roberts, T. P., \& Zigarmi, D. (2014). The impact of dispositional cynicism on job-specific affect and work intentions. International Journal of Psychology, 49(5), 381-389. https://doi.org/10.1002/ijop.12051

Rodwell, J., McWilliams, J., \& Gulyas, A. (2017). The impact of characteristics of nurses' relationships with their supervisor, engagement and trust, on performance behaviours and intent to quit. Journal of advanced nursing, 73(1), 190-200. https://doi.org/10.1111/jan.13102

Rost, J. C. (1993). Leadership for the twenty-first century. Greenwood Publishing Group.

Rubin, R. S., Munz, D. C., \& Bommer, W. H. (2005). Leading from within: The effects of emotion recognition and personality on transformational leadership behavior. Academy of Management Journal, 48(5), 845-858. https://doi.org/10.5465/amj.2005.18803926

Salovey, P., \& Mayer, J. D. (1990). Emotional intelligence. Imagination, cognition and personality, 9(3), 185-211. https://doi.org/10.2190/DUGG-P24E-52WK-6CDG

Shaukat, R., Yousaf, A., \& sanders, K. (2017). Examining the linkages between relationship conflict, performance and turnover intentions: Role of job burnout as a mediator. International Journal of Conflict Management, 28(1). https://doi.org/10.1108/IJCMA-08-2015-0051

Sheeran, P. (2002). Intention - Behavior relations: A conceptual and empirical review. European Review of Social Psychology, 12, 1-36. https://doi.org/10.1080/14792772143000003

Shockley, K. M., Ispas, D. R., Michael, E., \& Levine, E. L. (2012). A meta-analytic investigation of the relationship between state affect, discrete emotions, and job performance. Human Performance, 25(5), 377-411. https://doi.org/10.1080/08959285.2012.721832

Shuck, B., \& Herd, A. M. (2012). Employee engagement and leadership: Exploring the convergence of two frameworks and implications for leadership development in HRD. Human resource development review. https://doi.org/10.1177/1534484312438211

Simić, I. (1998). Transformational leadership-the key to successful management of transformational organizational changes.

Sniehotta, F. F., Presseau, J., \& Araújo-Soares, V. (2014). Time to retire the theory of planned behaviour. Health 
Psychology Review, 8(1), 1-7. https://doi.org/10.1080/17437199.2013.869710

Sonnentag, S., \& Frese, M. (2012). Dynamic performance. The Oxford handbook of organizational psychology, 548-575. https://doi.org/10.1093/oxfordhb/9780199928309.013.0017

Sony, M., \& Mekoth, N. (2015). Fleadapt scale: A new tool to measure frontline employee adaptability in power sector. International Journal of Energy Sector Management. https://doi.org/10.1108/IJESM-05-2014-0005

Standing, O., Standing, S., Kordt, E., \& Standing, C. (2016). Explaining Attribution in Information Technology Projects. Journal of Systems and Information Technology, 18(2). https://doi.org/10.1108/JSIT-01-2016-0002

Strizhakova, Y., \& Tsarenko, Y. (2017). Coping with service failures: The role of emotional intelligence, self-efficacy and intention to complain. In The Customer is NOT Always Right? Marketing Orientationsin a Dynamic Business World (pp. 654-654). Springer, Cham. https://doi.org/10.1007/978-3-319-50008-9_176

Teepapal, T. (2013). The determinants of subordinates' perceived leadership styles in small and medium enterprises in Thailand. AU Journal of Management, 11(1).

Tjosvold, D. (1985). Implications of controversy research for management. Journal of management, 11(3), 21-37. https://doi.org/10.1177/014920638501100303

Triandis, H. C. (1980). Reflections on trends in cross-cultural research. Journal of cross-cultural psychology, 11(1), 35-58. https://doi.org/10.1177/002202218011

UNIVERSITAS. (2020). U21 ranking of national higher education systems 2020 released. Retrieved from https://universitas.com

Vidyarthi, P. R., Anand, S., \& Liden, R. C. (2014). Do emotionally perceptive leaders motivate higher employee performance? The moderating role of task interdependence and power distance. The Leadership Quarterly, 25(2), 232-244. https://doi.org/10.1016/j.leaqua.2013.08.003

Vierimaa, J. (2013). Emotional Intelligence and Project Leadership (Unpublished MA Thesis). Göteborg, Sweden: Chalmers University of Technology.

Vollenwyder, B., Iten, G. H., Brühlmann, F., Opwis, K., \& Mekler, E. D. (2019). Salient beliefs influencing the intention to consider web accessibility. Computers in Human Behaviour, 92, 352-360. https://doi.org/10.1016/j.chb.2018.11.016

Walters, T. M. (2018). The relationship between emotional intelligence and career intentions of first-year college students at historically black institutions in the southeast (Doctoral's dissertation). Benedictine University, Illinois, USA.

Webb, T. L., \& Sheeran, P. (2006). Does changing behavioral intentions engender behavior change? A meta-analysis of the experimental evidence. Psychological bulletin, 132(2), 249. https://doi.org/10.1037/0033-2909.132.2.249

Weiner, B. (1987). The social psychology of emotion: Applications of a naive psychology. Journal of Social and Clinical Psychology, 5(4), 405. https://doi.org/10.1521/jscp.1987.5.4.405

Weiner, B. (1995). Judgments of responsibility: A foundation for a theory of social conduct. Guilford Press.

Yoke, L. B., \& Panatik, S. A. (2015). Emotional intelligence and job performance among school teachers. Asian Social Science, 11(13), 227. https://doi.org/10.5539/ass.v11n13p227

Yukl, G. (1999). An evaluation of conceptual weaknesses in transformational and charismatic leadership theories. The leadership quarterly, 10(2), 285-305. https://doi.org/10.1016/S1048-9843(99)00013-2

Yukl, G. A. (2002). Leadership in organizations.

Yukl, G., \& Mahsud, R. (2010). Why flexible and adaptive leadership is essential. Consulting Psychology Journal: Practice and Research, 62(2), 81. https://doi.org/10.1037/a0019835

Zigarmi, D., \& Roberts, T. P. (2012). Leader values as predictors of employee affect and work passion intentions. Journal of Modern Economy and Management, 1(1), 1-28.

\section{Copyrights}

Copyright for this article is retained by the author(s), with first publication rights granted to the journal.

This is an open-access article distributed under the terms and conditions of the Creative Commons Attribution license (http://creativecommons.org/licenses/by/4.0/). 